\title{
First records of three cepheid jellyfish species from Sri Lanka with redescription of the genus Marivagia Galil and Gershwin, 2010 (Cnidaria: Scyphozoa: Rhizostomeae: Cepheidae)
}

\author{
Krishan D. Karunarathne and M.D.S.T. de Croos* \\ Department of Aquaculture and Fisheries, Faculty of Livestock, Fisheries and Nutrition, \\ Wayamba University of Sri Lanka, Makandura, Gonawila (NWP), 60170, Sri Lanka. \\ *Correspondence (dileepa_dc@yahoo.com,dileepad@wyb.ac.lk) \\ https://orcid.org/0000-0003-4449-6573
}

Received: 09.02.2020 Revised: 01.08.2020 Accepted: 17.08.2020 Published online: 15.09.2020

\begin{abstract}
Cepheid medusae appeared in great numbers in the northeastern coastal waters of Sri Lanka during the nonmonsoon period (March to October) posing adverse threats to fisheries and coastal tourism, but the taxonomic status of these jellyfishes was unknown. Therefore, an inclusive study on jellyfish was carried out from November 2016 to July 2019 for taxonomic identification of the species found in coastal waters. In this study, three species of cepheid mild stingers, Cephea cephea, Marivagia stellata, and Netrostoma setouchianum were reported for the first time in Sri Lankan waters. Moreover, the diagnostic description of the genus Marivagia is revised in this study due to the possessing of appendages on both oral arms and arm disc of Sri Lankan specimens, comparing with original notes and photographs of M. stellata.
\end{abstract}

Keywords: Indian Ocean, invasiveness, medusae, morphology, taxonomy

\section{INTRODUCTION}

The class Scyphozoa under the phylum Cnidaria consists of true jellyfishes. They are mostly known as problematic marine organisms due to their ability to cause adverse impacts on both environmental and socioeconomic status of a country. Some of the jellyfish species are hazardous to health; bloom forming jellyfish can break down coastal power plants; fish landings can get reduced when jellies clog into fishing nets and also when jellies intensively predate on larvae/eggs of commercially important food fishes (Purcell et al. 2007; Richardson et al. 2009). Moreover, marine ecosystems can adversely be affected if scyphomedusae become invasive (Purcell et al. 2007; Richardson et al. 2009). However, they are reported to be highly beneficial in socioeconomic and ecological aspects. For example, some of the scyphomedusae are harvested in mass quantities for edible purpose (Kingsford et al. 2000; Hsieh et al. 2001; Omori and Nakano 2001; Brotz and Pauly 2017) while, some are widely used as ornamental species in marine aquarium trade and zoos (AZA 2013). When considering the ecological benefits, they show symbiotic relationships with other fauna (Purcell and Arai 2001), and even dead jellyfish blooms can transfer mass quantities of nutrients into the sea floor (Lebrato et al. 2012).

Scyphomedusae have been reported from all oceans around the world. The Indo-Pacific is a hot-spot for cepheid medusae (Galil et al. 2010), which mostly represent crowned jellyfish species belonging to the genera, Cephea Péron \& Lesueur, 1810, and Netrostoma Schultze, 1898. Cephea cephea (Forskål, 1775) and Netrostoma setouchianum (Kishinouye, 1902) are such common crowned jellyfish species reported in the Indo-Pacific region (Mayer 1910; Menon 1930; Kramp 1961; Gul et al. 2015b, c). Cephea cephea was originally described from the Red Sea, and even recently huge blooms have been reported in the same waters of the Indian Ocean (CruzRivera and El-Regal 2015) while, $N$. setouchianum was frequently reported in Japanese waters (Kramp 1961). Marivagia stellata Galil \& Gershwin, 2010 is also a cepheid, but is not referred as a crowned jellyfish. It was originally described as an alien species to the Mediterranean Sea, introduced from its native locality of the Indian Ocean through the Suez Canal (Galil et al. 2010). Later, M. stellata was reported to be invasive on Mediterranean waters 
(Galil and Goren 2014) while, huge blooms were observed in the Indian waters (Raphael et al. 2017), and even in the present study we observed the occurrence of M. stellata blooms off the east coast of Sri Lanka.

Sri Lanka (former Ceylon) is an island country located in between the Arabian Sea and the Bay of Bengal, neighboring to India from northern border and close to the equator from the southern boundary of Exclusive Economic Zone (EEZ). Due to its significant geographical location, Sri Lanka has become a biodiversity hotspot by having most of the marine ecosystems which exist in the tropical region of the Indian Ocean. However, the taxonomic status of scyphozoans in Sri Lankan waters is very poorly known due to lack of studies conducted so far (Karunarathne and de Croos 2020). Stiasny (1931) identified Crambione mastigophora Maas, 1903 by re-inspection of two museum specimens collected from Sri Lanka; also, Lychnorhiza malayensis Stiasny, 1920 and Cassiopea andromeda (Forskål, 1775) were reported by Fernando (2006) and Karunarathne et al. (2020) respectively. However, there are no any more reliable records up to the species level, of the other rhizostome jellyfish of Scyphozoa identified from Sri Lankan waters. In this context, here we report three more species of scyphomedusae which belong to the family Cepheidae, found from Sri Lankan waters, while revising the diagnostic description of the genus Marivagia Galil \& Gershwin, 2010 after careful inspection of $M$. stellata specimens, which were collected from its native locality of the Indian Ocean.

\section{MATERIALS AND METHODS}

A systematic, year-round jellyfish survey was conducted in shallow waters around Sri Lanka from November 2016 to April 2018 (fourmonth pilot study + fourteen-month main survey) by using a towed net (diameter $1 \mathrm{~m}$; mesh size 1 $\mathrm{mm}$ ), a standard trammel net (length $500 \mathrm{~m}$; height $10 \mathrm{~m}$; inner mesh $2.5 \mathrm{~cm}, 2$ ply, hanging ratio $=0.5$; outer mesh $12.7 \mathrm{~cm}, 4$ ply, hanging ratio $=0.5$ ), and a scoop net (mesh size $5 \mathrm{~mm}$ ). Meanwhile, jellyfish entangled to commercial fishing gear, i.e. beach seins, purse seines, trawling nets, and gillnets during November 2016 to July 2019 were also collected at landing sites and investigated taxonomically.

Altogether 38 specimens belonging to $M$. stellata and a single specimen of $N$. setouchianum were collected from several localities $(L)$ around Sri Lanka (Fig. 1 and Table 1). These medusae were photographed in life after dipping in an artificial tank, followed by transportation to the laboratory, in preserved form, using $5 \%$ formaldehyde/seawater buffer solution. At each sampling site if jellyfish were found, respective water quality parameters namely, temperature, dissolved oxygen, $\mathrm{pH}$, salinity, total dissolved solids, electrical conductivity, resistivity, and turbidity were recorded by using a digital multiparameter instrument (HACH HQ $40 \mathrm{D}$ ), and a portable turbidity meter (HACH 2100P) in understanding the preferable water quality conditions of jellies. Coordinates of each sampling location were recorded with a GPS unit (GARMIN 72H).

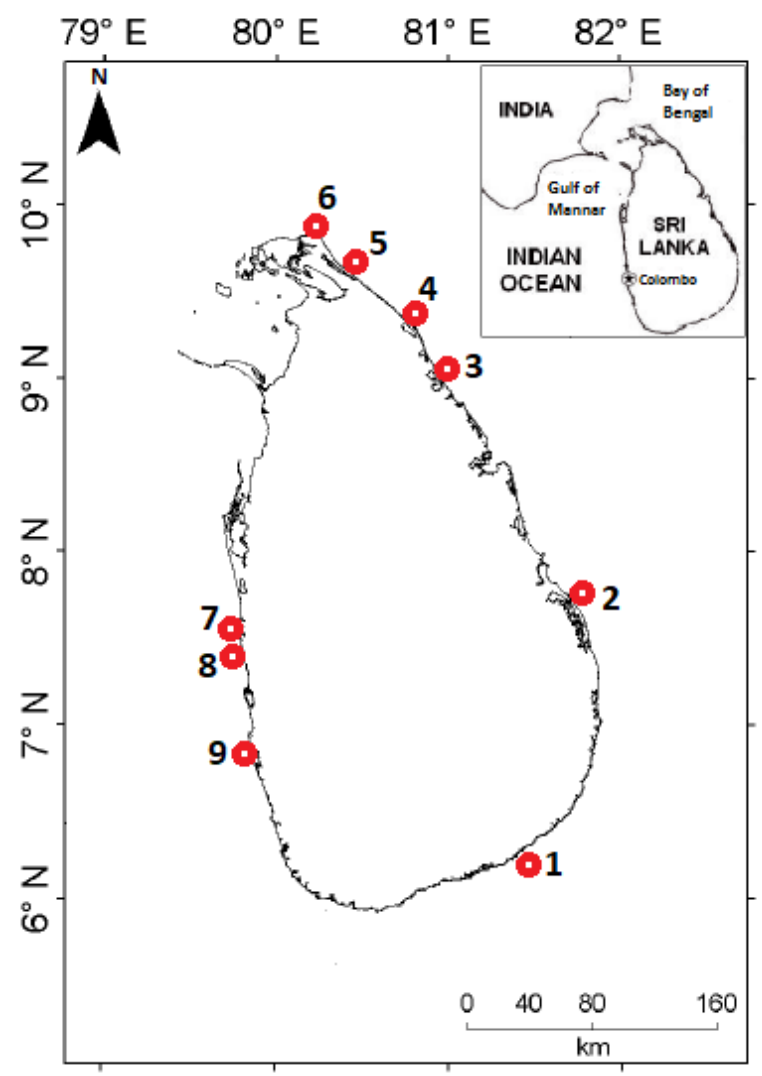

Fig 1 Nine localities where specimens of cepheid medusae were collected from the coastal waters around Sri Lanka (indicated by open circles). The names and exact GPS positions of these sampling locations are given in Table 1.

In addition, two more specimens of $M$. stellata, and one specimen of $C$. cephea, which had been collected by scuba divers, using polybags, from the west and the south coasts of Sri Lanka were also provided to the present study. 
Table 1 Coastal localities of Sri Lanka where the cepheid medusae specimens were sampled. Sampling locations, 1-9 are indicated in Fig. 1.

\begin{tabular}{lll}
\hline \multicolumn{2}{l}{ Sampling location $(L)$} & GPS coordinates \\
\hline 1 & Great Basses & Not available \\
2 & Kallady & $7.7382^{\circ} \mathrm{N}, 81.7611^{\circ} \mathrm{E}$ \\
3 & Kokkilai & $9.0169^{\circ} \mathrm{N}, 81.0018^{\circ} \mathrm{E}$ \\
4 & Putumattalan & $9.3961^{\circ} \mathrm{N}, 80.7612^{\circ} \mathrm{E}$ \\
5 & Thalayadi & $9.6686^{\circ} \mathrm{N}, 80.4307^{\circ} \mathrm{E}$ \\
6 & Point Pedro & $9.8717^{\circ} \mathrm{N}, 80.2547^{\circ} \mathrm{E}$ \\
7 & Chilaw & $7.6046^{\circ} \mathrm{N}, 79.7390^{\circ} \mathrm{E}$ \\
8 & Wennappuwa & $7.3528^{\circ} \mathrm{N}, 79.8256^{\circ} \mathrm{E}$ \\
9 & Wellawatte & Not available \\
\hline
\end{tabular}

Identification of these three species were done following their original descriptions [Forskål (1775); Kishinouye (1902); Galil et al. (2010)], Stiasny (1937), and Kramp's (1961) synopsis of the medusae of the world. Dimensional characteristics (i.e. bell diameter, length of appendages found on both oral arms and arm disc) of these specimens were measured to the nearest millimeter. After the morphological identification, all the specimens have been deposited in the Museum of Department of Aquaculture and Fisheries, Wayamba University of Sri Lanka (MDAFWU) with respective specimen accession numbers.

\section{RESULTS AND DISCUSSION}

\section{Systematic position of cepheids:}

Phylum Cnidaria Verrill, 1865

Subphylum Medusozoa Petersen, 1979

Class Scyphozoa Götte, 1887

Order Rhizostomeae Cuvier, 1800

Suborder Kolpophorae Stiasny, 1920

Infraorder Actinomyaria Stiasny, 1920

Family Cepheidae Agassiz, 1862

Stiasny (1921) and Kramp (1961) separated genera of the family Cepheidae, based on the number of radial canals per octant. Five genera have been classified under Cepheidae; of them, Polyrhiza Agassiz, 1862 has been considered as a doubtful genus (Kramp 1961). Other four genera have simply been distinguished on the morphological features through several taxonomic studies (Table 2).

\section{Genus Cephea Péron \& Lesueur, 1810}

Species Cephea cephea (Forskål, 1775) (Fig. 2)

Material examined: 1 specimen (MDAFWU 2019/81), $L_{1}$, coll. in March 2008.

Description: Bell wide, $300 \mathrm{~mm}$ in diameter, about 3 times wider than height, with central dome bearing 30 difference sized, pointed to rounded, gelatinous protuberances, surrounded by a deep annular furrow on the exumbrella (Fig. 2A, B, D). Velar lappets 64 (eight per octant) rounded, united by a membrane (Fig. 2D, E). Rhopalia 8, 4 perradial and 4 interradial; each rhopalium sided by two, very small, pointed rhopalar lappets (Fig. 2E). Subumbrellar circular musculature weak, near the bell margin; radial musculature beams-shaped. Arm disc massive, octagonal. Oral arms 8, about half of bell radius, each arm bifurcating basally making 8 main groups of branches extending slightly beyond disc margin; mouthlets numerous; several short clubs and long, hollow, slender tapering filaments between the branches, filaments lengthy up to 2 times of disc diameter (Fig. 2C). Subgenital ostia 4, small and round, without papillae. Gonads 4, interradial, crescentic and entirely enclosed. Radial canals 48 (8 rhopalar canals plus 5 inter-rhopalar canals per octant), linked distally by anastomosing network; ring canal absent (Fig. 2E). Colouration: umbrella blue; oral arms bluish-brown; short clubs whitish; filaments colourless (Fig. 2A-D).

Remarks: Of the four certain genera in the family Cepheidae, Cephea and Netrostoma are known as two closely related genera, which are separated morphologically based on the number of interrhopalar canals per octant, and the presence/absence of subumbrellar appendages and their shape (Table 2). The unique character of Netrostoma is the presence of short appendages on mouth arms while, Cephea having numerous long, pointed 'lash-like filaments' on mouth arms (Menon 1930; Kramp 1961; Gul et al. 2015a, c).

There are four accepted species in the genus Cephea. Of them, C. cephea owns marginal lappets while, they are absent in Cephea coerulea Vanhöffen, 1902, and both of these species have been reported in the Indian Ocean (Kramp 1961; Gul et al. 2015b, c). As the prominent marginal lappets are possessed by Sri Lankan Cephea specimen (Fig. 2D, E), which can easily be distinguished from $C$. coerulea. The Cephea 
Table 2 Distinction amongst certain genera of the family Cepheidae Agassiz, 1862. Information from Mayer (1910), Kramp (1961), Gershwin and Zeidler (2008), and Galil et al. (2010).

\begin{tabular}{|c|c|c|c|}
\hline \multirow[t]{2}{*}{ Genus } & \multicolumn{3}{|c|}{ Key morphological features } \\
\hline & Nature of exumbrella & Nature of appendages & $\begin{array}{l}\text { Number of inter-rhopalar } \\
\text { canals per octant }\end{array}$ \\
\hline $\begin{array}{l}\text { Cephea Péron \& } \\
\text { Lesueur, } 1810\end{array}$ & $\begin{array}{l}\text { With a dome bearing } \\
\text { warts/protuberances }\end{array}$ & $\begin{array}{l}\text { Oral arms and arm disc with } \\
\text { long, pointed filaments }\end{array}$ & More than three \\
\hline $\begin{array}{l}\text { Cotylorhiza } \\
\text { Agassiz, } 1862\end{array}$ & $\begin{array}{l}\text { With a dome without } \\
\text { warts/protuberances }\end{array}$ & $\begin{array}{l}\text { Oral arms with filaments with } \\
\text { expanded ends/suckers }\end{array}$ & Up to thirteen \\
\hline $\begin{array}{l}\text { Marivagia Galil } \\
\text { \& Gershwin, } \\
2010\end{array}$ & $\begin{array}{l}\text { Without dome, } \\
\text { warts/protuberances or } \\
\text { knobs }\end{array}$ & No appendages* & Three \\
\hline $\begin{array}{l}\text { Netrostoma } \\
\text { Schultze, } 1898\end{array}$ & $\begin{array}{l}\text { With a dome bearing } \\
\text { warts/protuberances or a } \\
\text { large, single central knob }\end{array}$ & $\begin{array}{l}\text { Oral arms with short spindle- } \\
\text { shaped appendages while, arm } \\
\text { disc with long filaments }\end{array}$ & Three \\
\hline
\end{tabular}

*Revised in the present study.
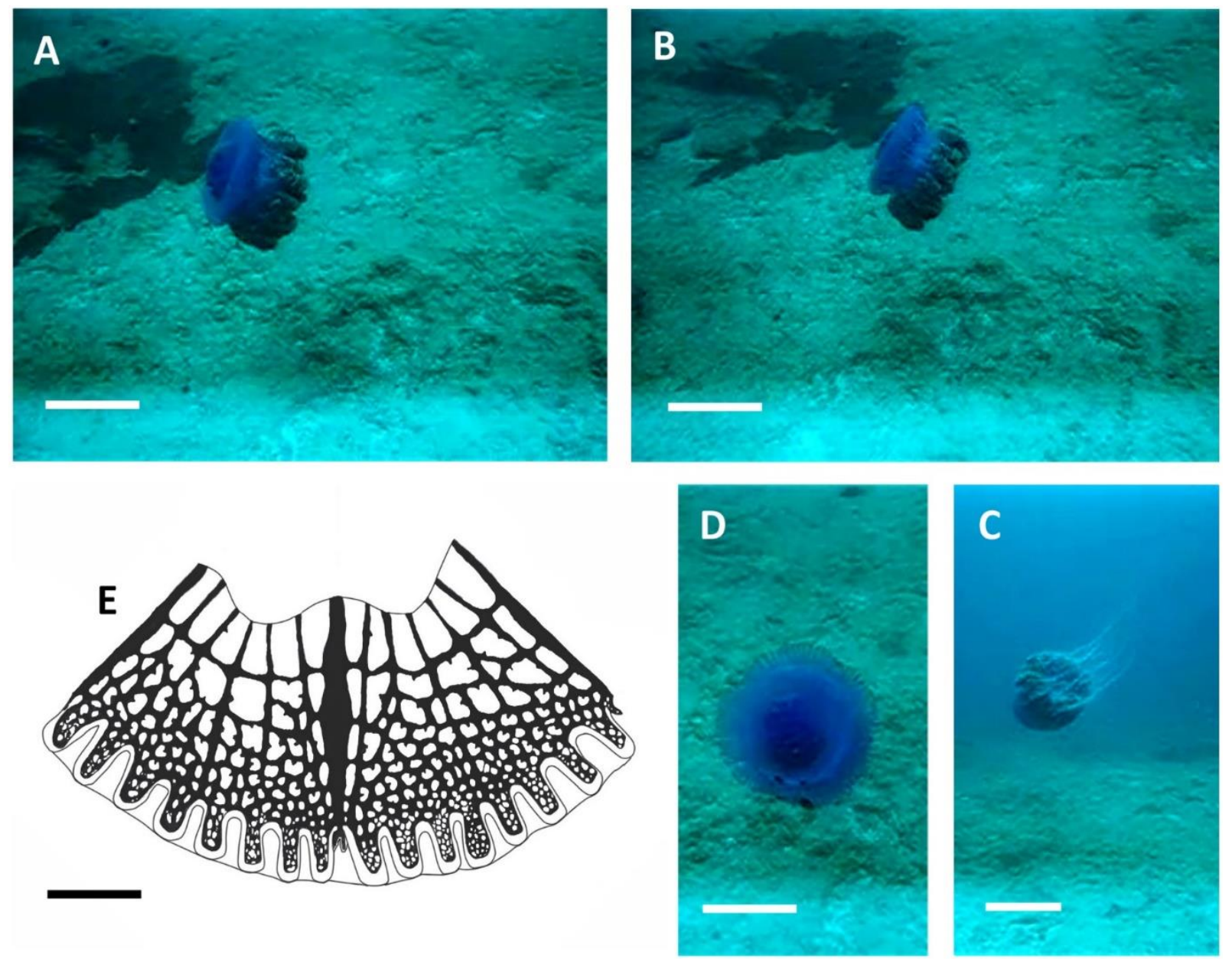

Fig 2 Cephea cephea (Forskål, 1775) (A-E): A \& B. Lateral view of a live medusa (MDAFWU 2019/81) found near bottom of the Great Basses, Sri Lanka (note the central dome of exumbrella); C. Oral view (note the long filaments on oral arms); D. Aboral view; E. Illustration of the anastomosing network of canal system. Scales: $E=30 \mathrm{~mm}$; A-D $=200 \mathrm{~mm}$. Images A-D by Vish Cumarasamy. 
octostyla (Forskål, 1775) is another originally described species from the Red Sea where the type locality of $C$. cephea. However, $C$. octostyla can also be differentiated from $C$. cephea because, exumbrella of $C$. octostyla has a zone of numerous stumpy warts leaving central portion free (Kramp 1961). Central dome of C. cephea bears around 30, different-sized, pointed to rounded gelatinous warts, without a warts-free zone (Kramp 1961) as same as the Sri Lankan specimen (Fig. 2D). The Cephea conifera Haeckel, 1880, reported in the tropical Pacific, is significant due to possessing of a single, long, stout filament from each of the four perradial corners of the ventral side of the arm disc and such a character is not owned by $C$. cephea (Kramp 1961) and the Sri Lankan specimen. The other morphological characters of the Cephea medusa which was found from Sri Lankan waters also tally with Kramp's (1961) description of $C$. cephea. Therefore, Sri Lankan Cephea specimen could clearly be identified as $C$. cephea .

Habitat in Sri Lanka: Marine; around reefs; near bottom (depth $10 \mathrm{~m}$ ).

Local names: Konda Gaduwa (in Sinhalese); Konda Soriyan (in Tamil).

Known importance: Cephea cephea has been reported as an edible jellyfish species which is harvested for food in Southeast Asia (Omori and Nakano 2001); and also, as an ornamental species in marine aquariums (AZA 2013). It plays an ecologically important role forming symbiotic relationships with some other fauna such as, the echinoderm Ophiocnemis marmorata (Lamarck, 1816) by being hosts (Marsh 1998), and with some medusivorous fish species such as, Zebrasoma desjardinii (Bennett, 1836) and Abudefduf vaigiensis (Quoy \& Gaimard, 1825) by being pray organisms (Cruz-Rivera and ElRegal 2016). In Sri Lankan waters, this medusa is important as a symbiont, which has been observed to be predated by adult fish of Siganus species (pers. comm. with some local divers who were engaged in mollusk shell collection in reef areas). Being an occasionally reported species, so far there is no risk of blooming C. cephea in Sri Lanka waters.

\section{Genus Marivagia Galil \& Gershwin, 2010}

\section{Species Marivagia stellata Galil \& Gershwin, 2010 (Fig. 3)}

Material examined: 2 specimens (MDAFWU 2017/146-147), $L_{2}$, coll. in July 2017., 1 specimen (MDAFWU 2018/88), $L_{3}$, April 2018., 7 specimens (MDAFWU 2017/155-161), $L_{4}$, June 2017., 15 specimens (MDAFWU 2017/10 24), $L_{5}$, June 2017., 4 specimens (MDAFWU 2017/231-234), $L_{6}$, October 2017., 2 specimens (MDAFWU 2017/240-241), $L_{7}$, July 2017., 7 specimens (MDAFWU 2019/99-105), $L_{8}$, February 2019., 2 specimens (MDAFWU 2019/1-2), L9, June 1997.

Description: Bell up to $200 \mathrm{~mm}$ in diameter, thinner at margin; exumbrella lacking central dome, conspicuous warts, papillae or knobs, draped only with a series of pigment marks (Fig. 3A, B). Velar lappets large, broad, distinct, tongue-shaped, typically six per octant (Fig. 3F). Rhopalia 8, 4 perradial and 4 interradial, within $\mathrm{W}$-shaped niches, roofed by a membrane. Rhopalar lappets smaller, shorter, narrower than velar ones (Fig. 3F). Subumbrella presence filaments on arm disk, up to $30 \mathrm{~mm}$ in length, four to numerous in number, covered by warts, tapering from base towards distal end, with terminal expansions (Fig. 3E); gelatinous radial ridges 9 per octant, extending from peripheral edge of gastrogonadal region halfway to margin. Oral arms 8, shorter than bell radius, triangular in cross section; spindle-shaped small appendages between feather-like mouths (Fig. 3C, D). Subgenital ostia 4, very small, without papillae. Gonads 4, interradial, crescentic and entirely enclosed. Radial canals 32 ( 8 rhopalar canals plus 3 inter-rhopalar canals per octant), loosely anastomosed proximally, complexly anastomosed in the distal region of bell (Fig. 3F). Colour translucent, purplish or bluish-white jelly, with obvious pattern of reddish stars, spots and streaks clustered in centre third of exumbrella; gonads pinkish-white; stomach region of subumbrellar surface covered with reddish spots; sometimes distal ends of oral arms reddish-brown (Fig. 3AC).

Remarks: Marivagia Galil \& Gershwin, 2010 is a monospecific genus, which consists of $M$. stellata (WoRMS Editorial Board 2020). Morphological features of exumbrella and canal system of Sri Lankan specimens are similar to the original description of $M$. stellata which was irradiated by Galil et al. (2010). Marivagia stellata found in the Lebanese waters was with clusters of spots in the center third of exumbrella (Bitar and Badreddine 2019); and also, the central part of exumbrella of the most of juveniles found from Sri Lanka was covered mainly with spots, when mature ones having spots, streaks and stars (Fig. 3B). Approximate bell size has been reported to about $150 \mathrm{~mm}$ by Galil et al. (2010) and Gul et al. (2014). Anyhow, 

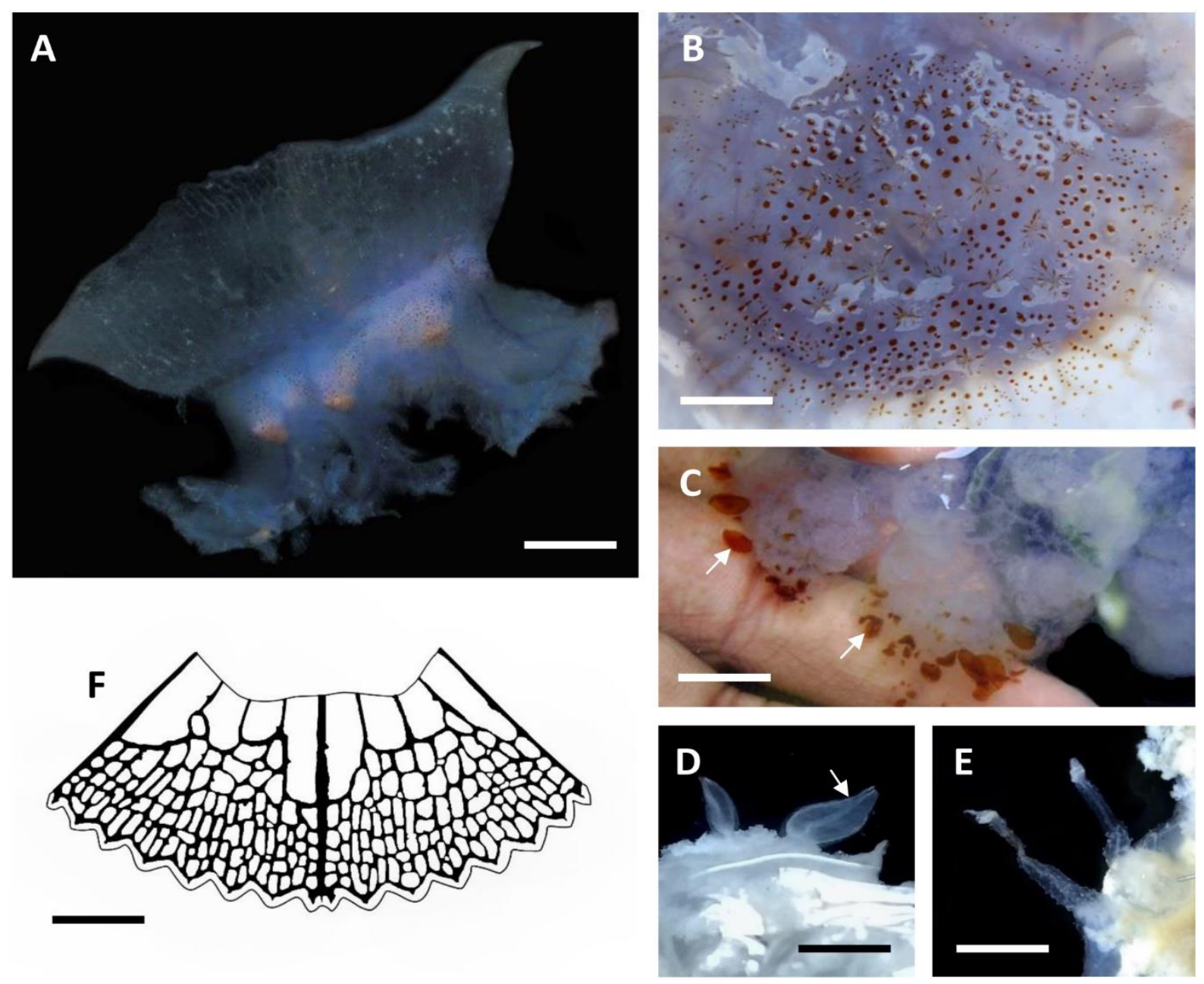

Fig 3 Marivagia stellata Galil \& Gershwin, 2010 (A-F): A. Lateral view of the medusa (MDAFWU 2017/10) in life; B. Characteristic star-marks with spots on the exumbrella; C \& D. Spindle-shaped appendages on oral arms (arrows); E. Filaments on the arm disc; F. Illustration of the anastomosing network of canal system. Scales: D $=5 \mathrm{~mm} ; \mathrm{B}, \mathrm{C}, \mathrm{E}=10 \mathrm{~mm}$; A, F $=20 \mathrm{~mm}$. Image $\mathrm{C}$ by Malik Fernando.

Bitar and Badreddine (2019) have reported $M$. stellata with a bell diameter of about $200 \mathrm{~mm}$; and they are as wide as the largest specimens found from Sri Lanka during the present study.

When concerning subumbrellar features, morphology of the oral arms and arm disc are altered from its original description due to presence of appendages (Fig. 3C-E). Original description of M. stellata was based on just two specimens and apparently Galil et al. (2010) have not found the appendages of type specimens probably be due to either to mechanical damage or natural (mutant) cause thus, there is no other reliable description on the morphology of $M$. stellata published up to now.

The tiny, spindle-shaped appendages are present on the latter portion of oral arms of Sri Lankan specimens (Fig. 3C, D); but holotype looks like to be lacking them (see Galil et al. 2010: Fig. 2B). However, the free-swimming medusae which have been observed in Mediterranean waters, which presented by Galil et al. (2010: Fig. 4) and Bitar and Badreddine (2019: Fig. 2), clearly show the presence of those appendages on its oral arms. This character exposed in Galil et al. (2010: Fig. 4) had also been noticed by Gul et al. (2015a). Therefore, the presence of those appendages on the latter portion of the oral arms of Marivagia is conformed. These spindle-shaped appendages in Sri Lankan specimens are mostly whitish or transparent in life. But in some medusae, distal ends of oral arms become dark due to the presence of some spindle-shaped appendages which are reddish-brown in colour (Fig. 3C) as same as in the Pakistani specimen reported by Gul et al. (2014: Fig. 1). 
Krishan D. Karunarathne and M.D.S.T. de Croos

Moreover, a few or several, short filaments were found on the arm disc of Sri Lankan specimens (Fig. 3E) while, the other features of the specimens comply with the original description and photographs. Galil et al. (2010) mentioned that the filaments are lacking on the arm disc of Marivagia by showing the subumbrella view of the holotype (see Galil et al. 2010: Fig. 2B); but the respective photograph does not make any clarification on either present or absent of filaments found on its arm disc because, most of those filaments are found to be tiny, curly and few in number if they are not vanished due to natural or artificial effect. As indicated by Galil et al. (2010), the native locality of M. stellata is the Indian Ocean and, it was repeatedly reported from India and Pakistan (Galil et al. 2013; Gul et al. 2014; Gul et al. 2015b; Raphael et al. 2017). Recent records greatly extend the range of its distribution to the northeast of the Arabian Sea (Gul et al. 2014) and adjacent areas; therefore, Sri Lankan specimens are good enough to examine for a taxonomic redescription of the genus Marivagia.

In this context, here we revise the original diagnostic description of the genus Marivagia Galil \& Gershwin, 2010 as follows;

"Cepheidae completely lacking exumbrellar central dome, papillae or knobs, with only microscopic warts and ridges; with subumbrellar appendages between the mouths and on the arm disc; with 3 adradial canals between rhopalar canals, anastomosing loosely in proximal region and complexly in distal region".

Diagnosis of the species Marivagia stellata Galil \& Gershwin, 2010 is as for the genus. Small, spindle-shaped appendages are present on oral arms, and short filaments are present on the arm disc while, the other features similar to its original description.

Habitat in Sri Lanka: Marine; near surface (depth $\quad 0-10 \mathrm{~m}$ ). Temperature $25.6-31.2^{\circ} \mathrm{C}$, dissolved oxygen 5.2-7.6 ppm, $\mathrm{pH}$ 7.4-8.4, salinity $28.5-33.5 \mathrm{ppt}$, total dissolved solids 27.9-32.0 ppt, electrical conductivity 55.8-61.4 $\mathrm{ms} / \mathrm{cm}$, resistivity $19.7-23.5 \Omega / \mathrm{cm}$, and turbidity 0.6-15.7 NTU.

Local names: Tharakā Horiya (in Sinhalese); Vinmeengal Soriyan (in Tamil).

Known importance: Both socioeconomic and ecological benefits of $M$. stellata are poorly reported in literature. Blooms have been observed to be adversely affecting on commercial fishing operations in the Indian waters (Raphael et al. 2017); and even in the Sri Lankan waters (authors' observations). The coastal tourism in the eastern province of Sri Lanka also reported to be adversely affected due to creating health issues among swimmers (pers. comm. with coastal life guards and hotel owners). Moreover, the ophiuroid $O$. marmorata was observed to be symbiotically associated with $M$. stellata (unpublished data of authors).

\section{Genus Netrostoma Schultze, 1898}

Species Netrostoma setouchianum (Kishinouye, 1902) (Fig. 4)

\section{Material examined: 1 specimen (MDAFWU}

2017/235), $L_{6}$, coll. in October 2017.

Description: Bell $80 \mathrm{~mm}$ in diameter, thinner at margin, bearing exumbrellar central dome with a distinct furrow around it (Fig. 4A). Dome with irregularly scattered, several, tiny, wart-like projections (Fig. 4B). Velar lappets round, distinct, 6-8 per octant; rhopalar lappets also distinct, smaller than velar lappets (Fig. 4E). Rhopalia 8, 4 perradial and 4 interradial. Arm disc wide, octagonal; center of arm disc with 8 , thin, transparent, small filaments up to $20 \mathrm{~mm}$ in length (Fig. 4C). Oral arms 8, short, about bell radius, triangular in cross section, bifurcated distally, bearing numerous tiny, lateral branches; numerous small, spindle-shaped appendages among frilled mouths (Fig. 4D). Subgenital ostia 4, small and round, without papillae. Gonads 4, interradial, crescentic. Subumbrellar circular musculature weak; radial muscles strongly developed, beam-shaped. Radial canals 32 (8 rhopalar canals plus 3 inter-rhopalar canals per octant), free proximally, anastomosed distally, without ring canal (Fig. 4E). Colour translucent bluish-white jelly, without colour patterns on exumbrella; sides of the arm disc covered with brownish spots; gonads pinkish; oral arms bluishwhite (Fig. 4A).

Remarks: There are four valid species of the genus Netrostoma Schultze, 1898 (WoRMS Editorial Board 2020). The number of warts/protuberances on the exumbrellar dome of Netrostoma species may vary with growth therefore it was not considered as a diagnostic character by Menon (1936) and Gul et al. (2015a). Morphological characters of the specimen found from Sri Lanka is similar to the original description of Netrostoma setouchianum 

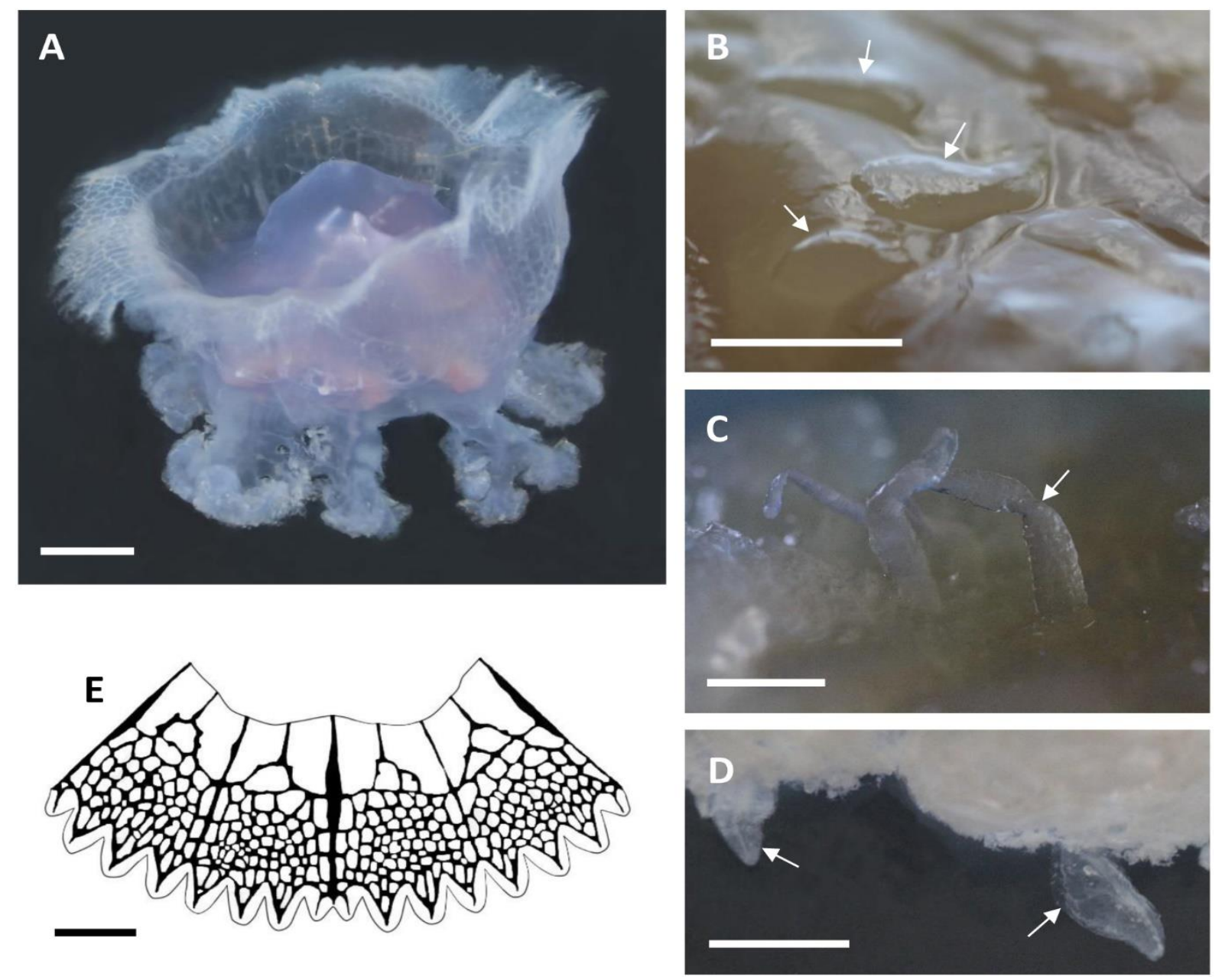

Fig 4 Netrostoma setouchianum (Kishinouye, 1902) (A-E): A. Side view of the medusa (MDAFWU 2017/235) in life (note the central dome of exumbrella); B. Close view of the central dome of exumbrella showing tiny, gelatinous projections (arrows); C. Filaments on the arm disc (arrow); D. Spindle-shaped appendages on the oral arms (arrows); E. Illustration of the anastomosing network of canal system. Scales: B, D = $5 \mathrm{~mm} ; \mathrm{A}, \mathrm{C}, \mathrm{E}=10 \mathrm{~mm}$.

(Kishinouye, 1902), but considerably smaller in size. This species can be found with up to 200 $\mathrm{mm}$ in bell diameter (Kishinouye 1902; Kramp 1961; Gul et al. 2015c); therefore, the number and the size of warts/protuberances on the exumbrellar dome were not considered for the diagnosis of Sri Lankan specimen too.

The recently described Australian species, Netrostoma nuda Gershwin \& Zeidler, 2008 owns a single, large, smooth central knob on the exumbrella (Gershwin and Zeidler 2008; Gul et al. 2015c), and it could easily be distinguished from the Sri Lankan specimen, which is having small projections on the central dome (Fig. 4B). Presence of scarcely distinguishable marginal lappets, and lacking of appendages on both the arm disc and mouth arms are significant morphological characters of the species reported around Fiji, Netrostoma dumokuroa (Agassiz \& Mayer, 1899) (Kramp 1961; Gul et al. 2015c), while the Sri Lankan specimen differs from $N$. dumokuroa by possessing of distinct marginal lappets and appendages on both the oral arms and arm disc (Fig. 4A, C-E).

Netrostoma coerulescens Maas, 1903 having two types of appendages between the mouths: one thin and tubular while the other is in spindleshape (Kramp 1961; Gershwin and Zeidler 2008). But Sri Lankan specimen was found with only small, spindle-shaped appendages on its oral arms (Fig. 4D); and thus, they could be distinguished. The Netrostoma typhlodendrium Schultze, 1898 has been synonymized to $N$. coerulescens by now (WoRMS Editorial Board 2020); and the distributions of $N$. coerulescens and $N$. setouchianum greatly overlap with each 
Krishan D. Karunarathne and M.D.S.T. de Croos

other, while their morpho-anatomical features mostly similar except the presence or absence of tiny, thin and tubular-shaped appendages between mouths. Probably N. coerulescens and $N$. setouchianum are not two distinct species, but a single species, however further studies are recommended to come up with a conclusion. Netrostoma coerulescens has been reported from Sri Lanka by Fernando (2006), but the relevant specimens (MDAFWU 2019/1-2) were reinspected during the present study and they were identified as $M$. stellata. Therefore, the record of $N$. coerulescens in Sri Lankan waters is no more valid.

Habitat in Sri Lanka: Marine; near surface (depth $1 \mathrm{~m}$ ). Temperature $27.6^{\circ} \mathrm{C}$, dissolved oxygen $6.6 \mathrm{ppm}, \mathrm{pH} 8.0$, salinity $29.8 \mathrm{ppt}$, total dissolved solids $28.8 \mathrm{ppt}$, electrical conductivity $51.0 \mathrm{~ms} / \mathrm{cm}$, resistivity $21.8 \Omega / \mathrm{cm}$, and turbidity 6.0 NTU.

Local names: Molli Gaduwa (in Sinhalese); Aeri Soriyan (in Tamil).

Known importance: Netrostoma species are ecologically important because, they became hosts for the brittle star $O$. marmorata found in Australian waters (Marsh 1998) while, Hashimoto et al. (2016) noted the predatory relationships of copepods, Paracalanus parvus (Claus, 1863) and Oithona sp. with $N$. setouchianum. However, no any importance of $N$. setouchianum has been reported from Sri Lanka. As occasionally reporting species, so far, $N$. setouchianum has no risk of blooming in Sri Lankan waters.

\section{ACKNOWLEDGEMENTS}

Authors are grateful to Dr. Malik Fernando and Mr. Vish Cumarasamy, who provided some additional specimens and photographs for the taxonomic identification of Sri Lankan cepheid jellyfishes. This study was supported by National Science Foundation (NSF) of Sri Lanka under the grant: RG/2016/OMR/01.

\section{REFERENCES}

AZA, Aquatic Invertebrate TAG 2013. Jellyfish Care Manual. Association of Zoos and Aquariums, Silver Spring, MD, 79 p.

Bitar, G. \& A. Badreddine 2019. First record of Marivagia stellata Galil and Gershwin, 2010 (Scyphozoa: Rhizostomeae: Cepheidae) from the Lebanese waters in the eastern Mediterranean Sea. Journal of the Black Sea/Mediterranean Environment 25(2): 172177.

Brotz, L. \& D. Pauly 2017. Studying jellyfish fisheries: toward accurate national catch reports and appropriate methods for stock assessments. In: G.L. Mariottini (ed.), Jellyfish: ecology, distribution patterns and human interactions, 313-329 pp. Nova Science Publishers.

Cruz-Rivera, E. \& M.A. El-Regal 2016. A bloom of an edible scyphozoan jellyfish in the Red Sea. Marine Biodiversity 46(2): 515-519. https://doi.org/10.1007/s12526-015-0381-1

Fernando, M. 2006. Coral associated invertebrates: An overview of the current taxonomic status. In: C.N.B. Bambaradeniya (ed.), The Fauna of Sri Lanka, Section 3: Status of Marine Fauna in Sri Lanka, 259273 pp. IUCN-The World Conservation Union, Colombo.

Forskål, P. 1775. Descriptiones animalium, avium, amphibiorum, piscium, insectorum, vermium: quae in itinere orientali observavit. ex officina Mölleri, 224 p. https://doi.org /10.5962/bhl.title. 2154

Galil, B.S. \& M. Goren 2014. Metamorphoses: Bioinvasions in the Mediterranean Sea. In: S. Goffredo \& Z. Dubinsky (eds), The Mediterranean Sea: Its history and present challenges, 463-478 pp. Springer, Dordrecht. https://doi.org/10.1007/978-94-007-67041_27

Galil, B.S., B.A. Kumar \& A.J. Riyas 2013. Marivagia stellata Galil and Gershwin, 2010 (Scyphozoa: Rhizostomeae: Cepheidae), found off the coast of Kerala, India. Bio Invasions Records 2(4): 317-318. https:// doi.org/10.3391/bir.2013.2.4.09

Galil, B.S., L. Gershwin, J. Douek \& B. Rinkevich 2010. Marivagia stellata gen. et sp. nov. (Scyphozoa: Rhizostomeae: Cepheidae), another alien jellyfish from the Mediterranean coast of Israel. Aquatic Invasions 5(4): 331-340. https://doi.org/10. 3391/ai.2010.5.4.01

Gershwin, L-A. \& W. Zeidler 2008. Two new jellyfishes (Cnidaria: Scyphozoa) from tropical Australian waters. Zootaxa 1764(1): 41-52. https://doi.org/10.11646/zootaxa.176 4.1 .4

Gul, S., A.C. Morandini \& M. Moazzam 2015a. First record of the crowned jellyfish Netrostoma coerulescens (Cnidaria: 
Scyphozoa) from Pakistani waters. Marine Biodiversity Records 8(e156):1-4. https:// doi.org/ 10.1017/S1755267215001268

Gul, S., A.C. Morandini, V. Häussermann \& U. Pörschmann 2015b. Checklist of cnidarians from Pakistani waters. Check List 11(1609): 1-8. https://dx.doi.org/10.15560/11.2.1609

Gul, S., M. Moazzam \& A.C., Morandini 2015c. Crowned jellyfish (Cnidaria: Scyphozoa: Rhizostomeae: Cepheidae) from waters off the coast of Pakistan, northern Arabian Sea. Check List 11(1): 1-4. https://doi.org/10.1 5560/11.1.1551

Gul, S., M. Moazzam \& B.S. Galil 2014. Occurrence of Marivagia stellata (Scyphozoa: Rhizostomeae: Cepheidae) along the coast of Pakistan, northern Arabian Sea. Marine Biodiversity Records 7(112): 12. https://doi.org/10.1017/S17552672140010 92

Hashimoto, S., S. Ohtsuka, Y. Kondo, S. Iwasaki, A. Adachi, H. Kasagawa \& Y. Koyano 2016. Feeding habits of Netrostoma setouchianum (Kishinouye, 1902) collected from the central part of the Seto Inland Sea, Japan. Bulletin of the Hiroshima University Museum 8: 39-43.

Hsieh, Y.H.P., F.M. Leong \& J. Rudloe 2001. Jellyfish as food. Hydrobiologia 451: 11-17. https://doi.org/10.1007/978-94-010-0722-1_2

Karunarathne, K.D. \& M.D.S.T. de Croos 2020. A new species of box jellyfish, Carybdea wayamba sp. nov. (Cnidaria: Scyphozoa: Cubomedusae: Carybdeida: Carybdeidae) from Sri Lanka. Plankton and Benthos Research (in press).

Karunarathne, K.D., S.M. Liyanaarachchi \& M.D.S.T. de Croos 2020. First record of upside-down jellyfish Cassiopea andromeda (Forskål, 1775) (Cnidaria: Scyphozoa: Rhizostomeae: Cassiopeidae) from Sri Lanka. Sri Lanka Journal of Aquatic Sciences 25(2): 57-65.

Kingsford, M.J., K.A. Pitt \& B.M. Gillanders 2000. Management of Jellyfish Fisheries, with Special Reference to the Order Rhizostomeae. Oceanography and Marine Biology: an Annual Review 38: 85-156.

Kishinouye, K. 1902. Some new scyphomedusae of Japan. College of Science, Tokyo Imperial University 17: 1-17.

Kramp, P.L. 1961. Synopsis of the medusae of the World. Journal of the Marine Biological Association of the United Kingdom 40: 7469. https://doi.org/10.1017/S002531540000 7347
Lebrato, M., K.A. Pitt, A.K. Sweetman, D.O. Jones, J.E. Cartes, A. Oschlies, R.H. Condon, J.C. Molinero, L. Adler, C. Gaillard, D. Lloris \& D.S.M. Billett 2012. Jelly-falls historic and recent observations: a review to drive future research directions. Hydrobiologia 690(1): 227-245. https:// doi.org/10.1007/s10750-012-1046-8

Marsh, L.M. 1998. Hitch-hiking ophiuroids. In: Echinoderms: San Francisco (R. Mooi \& M. Telford eds), pp. 393-396, International Echinoderm Conference Proceedings 9, 923 p. A.A. Balkema, Rotterdam.

Mayer, A.G. 1910. Medusae of the World, Scyphomedusae, vol. III. Carnegie Institution, Washington DC, 735 p. https://doi.org/10.5962/bhl.title.159245

Menon, M.G.K. 1930. The Scyphomedusae of Madras and the Neighbouring Coast. Bulletin of the Madras Government Museum 3: 1-28.

Menon, M.G.K. 1936. Scyphomedusae of Krusadai Island. Bulletin of the Madras Government Museum, New Series, Natural History Section 1: 1-9.

Omori, M. \& E. Nakono 2001. Jellyfish fisheries in Southeast Asia. Hydrobiologia 451: 19-26. https://doi.org/10.1007/978-94-010-0722-1_3

Purcell, J.E. \& M.N. Arai 2001. Interactions of pelagic cnidarians and ctenophores with fish: a review. Hydrobiologia 451: 27-44. https://doi.org/10.1007/978-94-010-0722-1_4

Purcell, J.E., I.U. Shin \& T.L. Wen 2007. Anthropogenic causes of jellyfish blooms and their direct consequences for humans: a review. Marine Ecology Progress Series 350: 153-174. https://doi.org/10.3354/meps07093

Raphael, L., R. Joseph \& L. Edwin 2017. Depredation and Catch Loss due to the Interaction of Aquatic Organisms with Ring Seines off Cochin Region. ICAR Fishery Technology 54: 66-70.

Richardson, A.J., A. Bakun, G.C. Hays \& M.J. Gibbons 2009. The jellyfish joyride: causes, consequences and management responses to a more gelatinous future. Trends in Ecology and Evolution 24(6): 312-322. https:// doi.org/10.1016/j.tree.2009.01.010

Stiasny, G. 1921. Studien über rhizostomeen. Capita Zoologica 1(8): 1-179.

Stiasny, G. 1931. Die Rhizostomeen-Sammlung des British Museum (Natural History); in London. Zoologische Mededelingen 14: 137178. 
Krishan D. Karunarathne and M.D.S.T. de Croos

Stiasny, G. 1937. Über Netrostoma setouchianum

Kishinouye, eine Rhizostomee von Suva

(Fidschiinseln). Zoologischer Anzeiger 120:

110-115.
WoRMS Editorial Board 2020. World Register of Marine Species. Available at: http:// www.marinespecies.org (accessed on 24 July 2020). 